\title{
Youtube Sebagai Sumber Informasi Bagi Peserta Didik di Masa Pandemi Covid-19
}

\author{
Fitroh Tri Utami ${ }^{1}$, Miefthaul Zanah ${ }^{2}$ \\ 1, 2, Universitas Indraprasta PGRI, Indonesia \\ ${ }^{1}$ tatatriutami5@gmail.com; ${ }^{2}$ miefthaulzanah@gmail.com
}

\begin{abstract}
Abstrak
Wabah Covid-19 yang masih mengalami fluktuatif membuat dunia pendidikan di Indonesia masih memberlakukan pembelajaran daring. Efek dari pembelajaran daring tersebut menuntut guru untuk lebih kreatif dan inovatif dalam menyampaikan materi kepada peserta didik. Guru harus mampu memilih media pembelajaran yang sesuai dengan materi yang akan diajarkan kepada peserta didik. Salah satu media yang sedang viral yaitu Youtube, sehingga artikel ini bertujuan untuk mengkaji potensi Youtube sebagai sumber belajar bagi peserta didik pada masa pandemi Covid-19. Metode yang digunakan dalam artikel ini yaitu kajian literatur. Berdasarkan hasil kajian literatur bahwa Youtube dapat digunakan sebagai sumber informasi bagi peserta didik untuk belajar memahami materi. Penggunaan Youtube sebagai sumber informasi juga dapat mengurangi kebosanan dan rasa jenuh peserta didik dalam proses pembelajaran. Youtube dapat menjadi media alternatif yang dapat digunakan untuk membantu menyelesaikan tugas dan sekaligus dapat menjadi sarana hiburan ketika lelah dengan berbagai tugas sekolah.
\end{abstract}

Kata Kunci: Covid-19, media sosial, media pembelajaran, pendidikan, YouTube

\section{Pendahuluan}

Corona Virus Disease 19 atau yang biasa disebut Covid 19 adalah sebuah penyakit menular yang diumumkan pertama kali pada bulan Desember tahun 2019 di Wuhan, China. Coronavirus menyerang sistem pernapasan manusia dan dapat menyebabkan infeksi ringan seperti flu atau yang lebih parah infeksi berat seperti infeksi paru-paru (pneumonia). Infeksi ini dapat menyebar ketika seseorang yang terpapar Covid-19 batuk, berbicara, atau bersin, dan dapat menyebar dari orang ke orang melalui percikan di hidung atau mulut (Organisasi Kesehatan Dunia, 2020).

Coronavirus telah menggemparkan berbagai negara di belahan dunia, salah satunya Indonesia. Hal ini menjadi tantangan bagi Indonesia untuk memutus mata rantai penyebaran wabah tersebut. Salah satu upaya pemerintah yaitu mengeluarkan himbauan untuk tidak berkerumun, saling menjaga jarak, menggunakan masker, dan mencuci tangan. Berdasarkan himbauan dari pemerintah tersebut, kemudian di respon oleh Kementerian Pendidikan dan Kebudayaan Republik Indonesia (Kemendikbud) yaitu dengan mengeluarkan Surat Edaran Nomor 4 Tahun 2020 tentang Pelaksanaan Kebijakan Pendidikan dalam Masa Darurat Penyebaran Covid-19. Kebijakan ini diberlakukan di berbagai sekolah yang ada di Indonesia. Melalui kebijakan tersebut, pemerintah meminta seluruh elemen pendidikan untuk dapat 
melakukan kegiatan belajar mengajar secara online dan menutup sementara aktivitas fisik di sekolah. Hal itu dianggap menjadi salah satu langkah yang efektif untuk memutuskan rantai penyebaran virus Covid-19 terhadap anak sekolah (Herliandry et al., 2020).

Pembelajaran online atau yang biasa dikenal sebagai Pembelajaran Jarak Jauh (PJJ) merupakan pembelajaran dimana peserta didik dan gurunya berada di lokasi terpisah, sehingga membutuhkan sistem telekomunikasi interaktif untuk menghubungkan keduanya (Syafnidawaty, 2020). Dengan adanya Pembelajaran Jarak Jauh, Guru dituntut untuk berpikir secara kreatif dan inovatif tentang bagaimana cara menyampaikan materi agar dapat dipahami oleh peserta didik. Selain itu, guru juga harus melihat keadaan dari masing - masing peserta didik, hal ini dikarenakan keadaan peserta didik berbeda satu dengan yang lainnya. Perbedaan tersebut dapat berupa perbedaan intelektual / IQ, kemampuan fisik, latar belakang keluarga, kebiasaan, fasilitas belajar, dan lain sebagainya (Ilyas, 2017). Perbedaan peserta didik tersebut juga menjadi tantangan seorang guru untuk menentukan media pembelajaran yang tepat agar materi bisa disampaikan secara optimal sehingga tujuan dari pembelajaran tersebut dapat tercapai.

Keterbatasan peserta didik dalam menangkap atau menyerap materi yang diajarkan oleh guru selama pembelajaran jarak jauh juga menjadi kendala dari tercapainya tujuan belajar. Oleh karena itu, guru harus dapat menggunakan media pembelajaran berbasis audio visual yang dapat diakses peserta didik secara berulang-ulang. Pemanfaatan media pembelajaran berbasis audio visual yang tepat, dapat membuat peserta didik lebih mudah menerima dan memahami materi yang disampaikan oleh guru.

Media pembelajaran audio visual banyak disukai oleh peserta didik karena media ini tidak hanya menampilkan tulisan berupa teks, tetapi juga menampilkan suara, sehingga peserta didik merasa ada yang menjelaskan materi yang mereka pelajari. Menurut Dwyer dalam Sadiman et. al (1996) pembelajaran berbasis video dapat membuat 94\% informasi masuk ke dalam otak peserta didik melalui mata dan telinga serta mampu membuat peserta didik mengingat $50 \%$ lebih tanggap dari apa yang mereka lihat dan dengar. Informasi yang disampaikan melalui media video dapat mempengaruhi emosi yang kuat dan bisa mencapai hasil yang cepat jika dibandingkan dengan media yang lain.

Media pembelajaran berbasis audio visual yang dapat dijumpai yaitu youtube. Guru dapat memanfaatkan media pembelajaran youtube untuk menjelaskan materi kepada peserta didik. Melalui youtube, guru dapat menampilkan video tentang materi pembelajaran yang akan diajarkan sehingga suasana belajar menjadi lebih inovatif, kreatif, menarik, dan tidak monoton. Penggunaan youtube sebagai media pembelajaran merupakan solusi yang sangat potensial untuk mengatasi keterbatasan informasi yang menyebabkan peserta didik banyak yang kurang paham tentang materi yang diajarkan. Melalui youtube, peserta didik bisa mempelajari atau bahkan mencari banyak hal tentang penjelasan lebih rinci dari suatu materi. Seperti contohnya pada pembelajaran matematika atau ekonomi, agar peserta didik dapat mengetahui lebih jelas alur perhitungan dari suatu materi maka ia dapat mencari dan menonton banyak video secara gratis yang diupload oleh masyarakat secara luas kapanpun dan dimanapun berada.

Media sosial Youtube sebagai sumber informasi belajar dapat membuat peserta didik memahami materi pelajaran dengan cepat dan meminimalisir rasa jenuh akibat pembelajaran jarak jauh. Dengan adanya media sosial youtube diharapkan dapat meningkatkan minat serta 
motivasi pada peserta didik. Youtube juga dapat digunakan oleh peserta didik tanpa terbatas oleh waktu, dengan catatan laptop atau handphone yang digunakan telah tersambung jaringan internet. Oleh karena itu, artikel ini bertujuan untuk mengkaji seberapa besar potensi penggunaan sosial media youtube sebagai sumber belajar peserta didik di masa pandemi Covid-19.

\section{Metode}

Metode yang digunakan dalam penelitian ini adalah kajian literatur yaitu dengan mencari dan melakukan analisis terhadap artikel - artikel yang telah diterbitkan sebelumnya mengenai pengaruh youtube terhadap pembelajaran peserta didik. kemudian menyimpulkan hasil dari artikel - artikel yang sudah dipilah sesuai dengan masalah dan tujuan penelitian.

\section{Pembahasan}

\section{Pemanfaatan Media Sosial}

Media sosial adalah sebuah sarana untuk berkomunikasi secara online di dunia maya yang berguna bagi penggunanya untuk mempermudah berpartisipasi, berkomunikasi, berinteraksi dan berbagi informasi secara cepat dan mudah. Saat ini media sosial sangat digemari masyarakat, mulai dari anak berusia 13 tahun hingga orang dewasa. Hal tersebut dapat dibuktikan dengan meningkatnya pengguna internet di setiap tahunnya. Hasil survei Asosiasi Penyelenggara Jasa Internet Indonesia (APJII) menunjukkan bahwa pada tahun 2018 jumlah pengguna internet di Indonesia mencapai angka 171,17 juta jiwa dari total keseluruhan penduduk Indonesia sebanyak 264,16 juta jiwa atau mencapai 64,8\%. Pada tahun 2019 - 2020 Kuartal II, jumlah pengguna internet ini semakin meningkat mencapai 196,71 juta jiwa dari total populasi penduduk yang mencapai 266,91 atau mencapai $73,7 \%$. Jumlah persentase terbesar berada di Pulau Jawa yaitu sekitar 56,6\%. Pada tingkat provinsi, pengguna internet di DKI Jakarta pada tahun 2018 mencapai angka 8,384 Juta penduduk dan tahun 2019 - 2020 mencapai angka 8.928 juta penduduk.

Penggunaan sosial media juga harus dikelola dengan baik agar penggunanya tidak menyalahgunakan pemanfaatan media sosial ke arah yang negatif. Penggunaan media sosial sebagai sumber belajar merupakan salah satu cara untuk mencegah dampak negatif dari media sosial tersebut. Dalam Pembelajaran Jarak Jauh (PJJ) guru memiliki peran yang sangat penting untuk memanfaatkan media sosial agar kegiatan belajar mengajar juga berjalan secara efektif, inovatif, kreatif, dan tidak monoton. Keberhasilan guru dalam melakukan pembelajaran jarak jauh dapat dilihat dari kemampuan guru dalam berinovasi merancang dan meramu materi, metode pembelajaran, media pembelajaran, dan menentukan aplikasi apa yang sesuai dengan materi yang akan diajarkan. Pada penelitian yang dilakukan oleh Mustakim (2020) bahwa pembelajaran daring pada mata pelajaran matematika menggunakan media sosial dinilai sangat efektif dengan besar persentase $23,3 \%$ dan ada sebagian besar menilai efektif dengan persentase $46,7 \%$ meskipun ada yang menganggap kurang efektif sebesar $10 \%$, dari hasil penelitian tersebut dapat ditarik kesimpulan bahwa penggunaan media sosial pada pembelajaran sangat efektif digunakan oleh guru pada masa pandemi saat ini. 


\section{Youtube}

Salah satu platform sosial yang dapat digunakan untuk pembelajaran daring yaitu platform sosial youtube. Media sosial ini dijalankan dengan basis situs web yang menyediakan berbagai macam video. Penggunaan youtube sebagai sumber pembelajaran mendapatkan respon positif dari peserta didik dikarenakan media youtube dapat menjelaskan materi secara audio visual, seperti layaknya guru menjelaskan di depan kelas. Hal lain yang membuat peserta didik lebih senang menggunakan youtube sebagai sumber belajar adalah karena mudahnya akses untuk menambah wawasan dan informasi yang mudah dipahami (Octaviani et al., 2019).

Berdasarkan analisa yang dilakukan oleh Asosiasi Penyelenggara Jasa Internet Indonesia (APJII, 2020) menyatakan bahwa $61 \%$ orang menyatakan sering menonton youtube dan $34,9 \%$ lainnya menyatakan hanya sesekali menonton youtube. Hal ini sejalan dengan data statistik Hootsuite We Are Social (Hootsuite, 2021) dari 271,35 juta penduduk Indonesia, 170,0 juta atau $61,8 \%$ nya merupakan pengguna aktif sosial media. Persentase total penggunaan sosial media yang mengakses menggunakan ponsel adalah sekitar 99,1\%. Hal ini menunjukkan bahwa masyarakat menghabiskan rata - rata waktunya sekitar 3 jam 14 menit dalam sehari untuk bermain sosial media. Youtube merupakan platform media sosial yang paling banyak digunakan dengan persentase 93,8\% yang kemudian disusul oleh whatsapp dengan persentase $87,7 \%$. Berdasarkan tingkat waktu kumulatif streaming video, youtube menduduki peringkat teratas sebagai aplikasi untuk streaming video dengan perkiraan waktu 25,9 jam per bulan.

Media sosial youtube memberikan sebuah dampak yang positif dan negatif terhadap pembelajaran. Adapun dampak positif dari pemanfaatan youtube sebagai media belajar adalah dapat memotivasi peserta didik untuk lebih banyak berkreasi, men dapatkan informasi yang berupa beragam video sebagai tutorial, serta dapat memperdalam materi yang telah diajarkan. Melalui youtube, peserta didik dapat memahami secara mendalam dari materi yang diajarkan guru karena youtube bisa menjadi contoh bentuk nyata dari materi yang dipelajari. Melalui youtube peserta didik juga dapat belajar secara mandiri, jadi tidak terlalu bergantung pada materi pembelajaran yang diberikan oleh guru di sekolah. Peserta didik juga dapat mencari dan menonton banyak informasi seputar materi yang akan diajarkan ataupun yang telah diajarkan (Marselina, 2019).

\section{Dampak Youtube Sebagai Media Pembelajaran}

Dengan youtube, semua materi pelajaran bisa didapatkan dengan mudah pada situs pelajaran (Oetomo, 2002). Pada awalnya, youtube hanya sebagai media sosial yang terbagi menjadi 3 buah video dan hanya dijadikan sebagai hiburan atas kesesakkan dari dunia pendidikan. Namun kini, youtube telah mempunyai jutaan video dari hasil unggahan para youtuber (sebutan untuk para pengunggah video di youtube) dan bisa menjadi sumber, atau bahan serta media pendidikan atau media pembelajaran yang dapat digunakan oleh guru, peserta didik, staf - staf sekolah bahkan orangtua atau wali peserta didik untuk mencari dan membantu setiap tugas - tugas yang ada.

Selain dampak positif yang ditimbulkan, youtube juga memiliki dampak negatif yang ditimbulkan. Dampak dari penggunaan media sosial youtube berupa rawan akan cyber bullying dan dapat mengakibatkan depresi kepada peserta didik. Selain itu, penggunaan youtube secara terus-menerus akan mengakibatkan rasa ketergantungan yang 
mengakibatkan peserta didik malas akan belajar. Banyaknya konten yang tidak mendidik dan berbau kriminal banyak sekali di upload oleh para content creator yang dapat mengakibatkan peserta didik mencontoh hal tersebut.

Untuk meminimalisir terjadinya dampak negatif tersebut diperlukan adanya pemberdayaan khususnya pada peserta didik yaitu dengan memperbanyak menonton konten yang bersifat edukatif atau konten yang bertemakan pendidikan. Berdasarkan data resmi yang telah dirilis oleh youtube, menyatakan bahwa salah satu fokus utama yang sedang dikembangkan adalah konten edukasi, karena melalui youtube setiap harinya ada lebih dari 1 miliar video yang berkaitan dengan proses pembelajaran (Youtube Creator Academy, 2018). Terdapat tiga genre utama terkait konten pendidikan yang dapat dibuat melalui youtube yaitu; (1) Edutainment' - yaitu konten yang mengkombinasikan antara dunia pendidikan dengan hiburan yang bertujuan untuk memberikan pembelajaran secara kreatif, inovatif dan mudah diingat. (2) Pendidikan serta jawaban langsung berisi petunjuk - petunjuk, pelajaran akademis, maupun berbasis kurikulum: Biasanya dipandu oleh guru atau oleh ahli. 3) Pembelajaran berbasis keahlian yaitu untuk mengarahkan dan meningkatkan karier: Biasanya dipandu oleh tenaga profesional dengan keahlian tertentu, ahli, atau organisasi yang memberikan pengajaran berbasis keahlian (Maulana, 2020). Pada penelitian yang dilakukan oleh Elce Pulwandari (2019) dengan judul pemanfaatan youtube sebagai sumber belajar fisika mengatakan bahwa $66 \%$ responden memanfaatkan youtube sebagai sumber belajar tambahan, dan $82 \%$ peserta didik lainnya menyelesaikan tugas melalui youtube serta $72 \%$ lainnya menjadikan youtube sebagai sarana hiburan. Dari penelitian tersebut, didapatkan hasil bahwa youtube adalah salah satu media alternatif untuk pembelajaran dan banyak digunakan oleh para peserta didik sebagai sumber pembelajaran, media untuk membantu menyelesaikan tugas dan menjadi sarana penghibur ketika lelah dengan berbagai tugas - tugas sekolah.

\section{Langkah - Langkah Menggunakan Youtube}

Berikut ini merupakan langkah - langkah untuk dapat menggunakan youtube secara optimal sebagai sumber belajar, yaitu 1) pada internet browser, ketikkan www.youtube.com untuk pergi ke laman website youtube, 2) kemudian ketikkan kata kunci atau istilah yang diinginkan untuk menjadi video yang sesuai pada kolom pencarian yang berlogo kacamata pembesar, 3) jika kata kunci sudah dimasukkan, klik "buka" pada keyboard ponsel atau "enter" pada keyboard komputer atau bisa juga mengklik kembali logo kacamata pembesar, 4) daftar video dengan judul dan thumbnailnya akan muncul secara otomatis, 5) untuk memutar video, silahkan pilih daftar judul yang sesuai dengan keinginan dan klik thumbnail video tersebut. Kemudian, video akan otomatis terputar, 6) pada bagian bawah layar video, ada logo pilihan untuk menjeda video, mundurkan penayangan, mempercepat, memperbesar layar menjadi full screen, dan mengatur intensitas volume suara. Terdapat juga timer untuk menampilkan durasi lamanya panjang video, 7) ketika video telah selesai diputar, terdapat pilihan untuk melanjutkan ke video yang lain atau dapat menonton kembali video yang telah selesai diputar tadi. Secara otomatis, judul dan thumbnail video yang serupa dengan video yang telah ditonton juga ditampilkan, 8) untuk dapat menyimpan video di situs youtube, bisa dengan mengklik "tambahkan ke favorit" atau menyalin link URL video dari kotak navigasi bagikan dan menggunakannya untuk membuat link sehingga lebih mudah untuk digunakan di kelas, 9) jika ingin mengetahui lebih lanjut mengenai youtube dan fungsinya dapat mengklik "bantuan" pada link (Burke \& Snyder, 2008). 


\section{Youtube Sebagai Sumber Belajar}

Berdasarkan pemaparan tentang media youtube di atas, bahwa youtube memiliki potensi yang cukup besar sebagai sumber belajar peserta didik selama masa pandemi covid19. Penggunaan youtube sebagai sumber belajar peserta didik dinilai mampu untuk menaikkan motivasi serta semangat belajarnya. Menurut penelitian yang dilakukan oleh Tohani et all. terdapat pengaruh yang substansial antara motivasi belajar peserta didik dengan penggunaan youtube. Dari hasil penelitian tersebut didapat $86,4 \%$ dan sisanya dipengaruhi oleh faktor lain (Tohari \& Bachri, 2019).

Youtube bisa menjadi sumber belajar jika guru tersebut memberikan sebuah arahan yang baik dan jelas dengan memberikan link youtube terkait materi yang diajarkan ataupun guru dapat membuat channel youtube sendiri. Dari sekian banyaknya video youtube, tak jarang banyak peserta didik yang merasa kebingungan. Oleh sebab itu, selain media pembelajaran yang efektif juga diperlukan peran guru dalam mengawasi dan memilah video video mana saja yang dapat digunakan peserta didik. Hal tersebut dilakukan agar meminimalisir dampak - dampak yang terjadi akibat penggunaan youtube sebagai sumber pembelajaran.

\section{Kesimpulan}

Berdasarkan hasil dan pembahasan dari tujuan tersebut, dapat ditarik kesimpulan bahwa dengan adanya pembelajaran jarak jauh, penggunaan youtube bisa dijadikan sebuah alternatif yang tepat sebagai media ajar yang digunakan selama proses belajar mengajar. Dengan menggunakan youtube, peserta didik menjadi lebih tanggap dalam menerima informasi tentang materi yang diajarkan oleh guru dan juga membantu dalam pengerjaan tugas, serta mendapatkan contoh nyata sebagai gambaran dari materi yang diajarkan. Penggunaan youtube sebagai media pembelajaran juga dapat meningkatkan semangat dan motivasi peserta didik karena dapat mengurangi rasa jenuh atau bosan, dan dapat meningkatkan pemahaman peserta didik terhadap materi yang diajarkan.

\section{Ucapan Terima Kasih}

Ucapan terimakasih kami berikan kepada Bapak Maskhur Dwi Saputra selaku dosen Penulisan IImiah yang telah memberikan bimbingan, saran dan arahan atas terbitnya artikel ini.

\section{Referensi}

APJII. (2020). Laporan Survei Internet APJII 2019 - 2020. Asosiasi Penyelenggara Jasa Internet Indonesia (Vol. 2020). Diambil dari https://apjii.or.id/survei

Burke, S. C., \& Snyder, S. L. (2008). YouTube: An Innovative Learning Resource for College Health Education Courses. International Electronic Journal of Health Education, 11, 3946.

Herliandry, L. D., Nurhasanah, N., Suban, M. E., \& Kuswanto, H. (2020). Pembelajaran Pada Masa Pandemi Covid-19. JTP - Jurnal Teknologi Pendidikan, 22(1), 65-70. https://doi.org/10.21009/jtp.v22i1.15286

Hootsuite, W. A. S. (2021). Data Pengguna Media Sosial di Indonesia Tahun 2021. Diambil 8 Juni 2021, dari https://www.iimers.com/data-pengguna-media-sosial-di-indonesia- 
tahun-2021/

Ilyas, S. (2017). Upaya Guru Memahami Kesulitan Belajar Siswa. Diambil 12 Juni 2021, dari https://portal.belitung.go.id/read-artikel/78/upaya-guru-memahami-kesulitan-belajarsiswa

Marselina, M. (2019). Pengaruh Pemanfaatan Media Sosial Youtube Terhadap Kemandirian Belajar Siswa Kelas IX SMP Negeri 2 Pontianak. Jurnal Pendidikan dan Pembelajaran Khatulistiwa, 8(7), 2019. Diambil dari https://jurnal.untan.ac.id/index.php/jpdpb/article/view/33734

Maulana, I. A. (2020). Pemanfaatan Media Youtube Dalam Meningkatan Keterampilan Berbicara Siswa SMA. In Transformasi Pendidikan Sebagai Upaya Mewujudkan Sustainable Development Goals (SDCS) di Era Society 5.0 (hal. 348-353). Majalengka: Universitas Majalengka.

Mustakim, M. (2020). Efektivitas Pembelajaran Daring Menggunakan Media Online Selama Pandemi Covid-19 Pada Mata Pelajaran Matematika. Al asma: Journal of Islamic Education, 2(1), 1. https://doi.org/10.24252/asma.v2i1.13646

Octaviani, M., Reza, M., Bajari, A., \& Suadnya, I. W. (2019). Pendidikan Tinggi Ilmu Komunikasi Menghadapi Revolusi Industri 4.0. (F. Junaedi \& I. R. Zarkasi, Ed.). Yogyakarta: Buku Litera.

Oetomo, B. S. D. (2002). E-education Konsep, Teknologi dan Aplikasi Internet Pendidikan (Vol. 1). Yogyakarta: Andi.

Organisasi Kesehatan Dunia. (2020). Q\&A Coronavirus. Diambil 10 Juni 2021, dari https://www.who.int/indonesia/news/novel-coronavirus/qa/qa-for-public

Purwandari, E. (2019). Pemanfaatan Youtube Sebagai Sumber Belajar Fisika. Journal of Education and Instruction (JOEAI), 2(2), 83-90. https://doi.org/10.31539/joeai.v2i2.810

Sadiman, A. S., Rahardjo, R., Harjito, \& Haryono, A. (1996). Media Pendidikan: Pengertian, Pengembangan, dan Pemanfaatannya. Jakarta: PT. Raya Grafindo Persada.

Syafnidawaty. (2020). Apa Itu Pembelajaran Jarak Jauh? Diambil 8 Juni 2021, dari https://raharja.ac.id/2020/11/17/apa-itu-pembelajaran-jarak-jauh/

Tohari, H., \& Bachri, B. S. (2019). Pengaruh penggunaan YouTube. Jurnal Teknologi Pendidikan, $7(1), 1-13$.

Youtube Creator Academy. (2018). Creator Academy. Diambil 10 Juni 2021, dari https://creatoracademy.youtube.com 